\title{
Le Néolithique moyen en Auvergne
}

Frédéric Jallet

URL : http://journals.openedition.org/adlfi/4864

ISSN : 2114-0502

Éditeur

Ministère de la culture

\section{Référence électronique}

Frédéric Jallet, "Le Néolithique moyen en Auvergne », ADLFI. Archéologie de la France - Informations [En ligne], Auvergne, mis en ligne le 01 mars 2006, consulté le 20 avril 2019. URL : http:// journals.openedition.org/adlfi/4864

Ce document a été généré automatiquement le 20 avril 2019.

(C) Ministère de la Culture et de la Communication, CNRS 


\title{
Le Néolithique moyen en Auvergne
}

\author{
Frédéric Jallet
}

Date de l'opération : 2006 (PC)

1 L'action collective de recherche (ACR) « Production et circulation des industries lithiques et céramiques en Auvergne dans le contexte chrono-culturel du Néolithique moyen » (Coordination: Cathy Georjon et Frédéric Jallet, INRAP) rassemble des archéologues de l'Inrap, du service régional de l'archéologie, du CNRS, de l'université et indépendants. Elle a vu le jour dans le cadre des appels à projet 2003, suite à un travail universitaire (Cathy Georjon, 1994) actualisé par les résultats de fouilles préventives dans une communication présentée au cours des «cinquièmes rencontres méridionales de préhistoire récente", tenues à Clermont-Ferrand en 2002 (Coordination Hélène Dartevelle, 2004).

2 Cette ACR a fait l'objet de deux rapports d'étape $(2005,2006)$; le second est en cours d'examen (avril 2007) par le Comité interinstitutionnel des ACR. La troisième, et dernière, année de cette ACR (2007) vise à réaliser la synthèse des travaux. Ils portent sur des fouilles programmées et préventives exécutées, principalement, dans les départements de la Haute-Loire et du Puy-de-Dôme. Cependant, l'ensemble du territoire régional est pris en compte (Allier, Cantal).

En 2005 et 2006, les industries lithiques et céramiques ont fait l'objet d'études typologiques, technologiques et pétrographiques. Ce sont ces données qui feront l'objet de croisements, par industries et par sites, au cours de l'année 2007. Après cette étape, l'objectif est d'identifier les chaînes opératoires, de reconnaître et de définir les composantes chrono-culturelles. Il sera dès lors possible de cerner l'évolution et de parvenir à identifier un phasage du Néolithique moyen de l'Auvergne, avec l'appui de nouvelles données radiocarbones. On essaiera d'évaluer le rôle des influences des groupes contemporains et le dynamisme (capacité de diffusion) du, ou des, faciès présents dans cet espace géographique. La prise en compte de cet espace (région Auvergne) et de la totalité du Néolithique moyen doit permettre d'illustrer la variabilité géographique et chronologique des composantes culturelles. 
Frédéric Jallet

INDEX

Index géographique : Auvergne

operation Projet collectif de recherche (PCR)

Thèmes : céramique, chaîne opératoire, industrie lithique, pétrographie, technologie de l'argile, technologie lithique, typologie, typologie lithique

Index chronologique : Néolithique

\section{AUTEURS}

FRÉDÉRIC JALLET

INRAP 